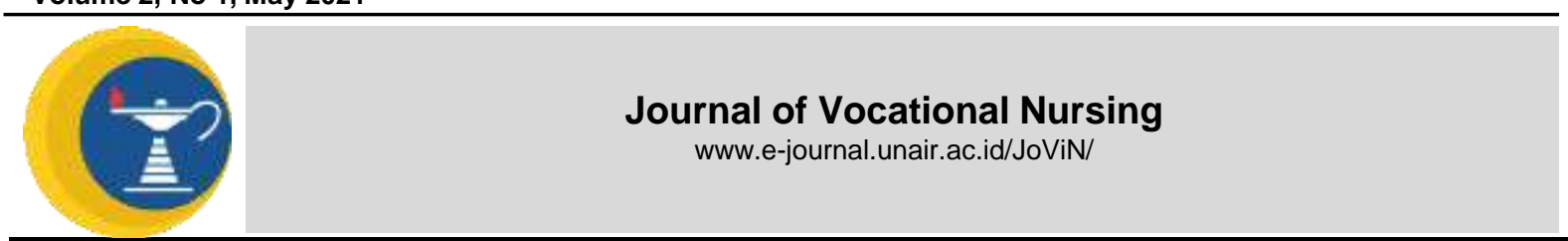

\title{
THE EFFECT OF KEGEL EXERCISE ON THE QUALITY OF LIFE IN POST TURP PATIENTS AT MUHAMMADIYAH HOSPITAL
}

\author{
Cucuk Rahmadi Purwanto, Yani Erniyawati, Susilo Harianto, \\ Hafna ILmy Muhalla, Fanni Okviasanti, Endah Sri Wijayanti \\ Faculty of Vocational Studies, Universitas Airlangga
}

Research Report

\begin{abstract}
A B S T RACT
Introduction: Urinary incontinence is a comorbid condition that often occurs in post TURP clients. Low urinary incontinence scores were found in post TURP clients who did Kegel exercises. The purpose of this study was to explain the effect of Kegel exercise on urinary incontinence, and quality of life in post- TURP clients. Methods: The study design was a true experiment pre-post test control group design. The sample size was 32 people who were selected by systematic random sampling, consisting of 16 people in the control group and 16 people in the group treatment. The independent variable in this study was Kegel exercise and the dependent variable was quality of life. Data were collected using a quality of life questionnaire with WHOQOL$B R E F$. Inferential analysis used statistical t $t$-test (Independent $t$-Test and Paired t-Test), MANOVA with a significance level of $\alpha \leq 0.05$. Results: The results showed that: Kegel exercises improve quality of life scores of the significance level $p=0.045$. Conclusion: Kegel exercise can build pubococcygeus muscle mass, improve blood circulation, and improve the bulbocavernosus and ischiocavernosus muscles, thereby reducing urinary incontinence, and quality of life for post TURP clients in a wider population by increasing the reach of the study population and increasing monitoring of client exercise.
\end{abstract}

\section{ARTICLE INFO}

Received May 01, 2021

Accepted May, 292021

Online May, 312021

*Correspondence:

Cucuk Rahmadi Purwanto

*Email:

pcucukrahmadi@vokasi.unair.ac.id

Keywords:

Kegel exercise, post TURP clients, quality of life

\section{INTRODUCTION}

Benigna Prostate Hypertrofi (BPH) is common in men over the age of 40 years. The prostate gland enlarges, extends upward into the bladder and blocks the outflow of urine. Incomplete emptying of the bladder and urinary retention resulting in urinary stasis can lead to hydronephrosis, hydroureter, and urinary tract infections (UTIs). The cause is unknown, but evidence suggests hormonal involvement(Janice \& Kerry, 2018)

Retention of urine continues to be the cause occurrence inkontinentia urine (IU) is a disorder of the fulfilment of elimination of urine. Urinary incontinence can be in the form of urine output that is sometimes very small (a few drops), very large, or uncontrollable (occurs against the will) (Rani et al., 2020). IU was found in post TURP or Trans Urethral Resection of the Prostate clients during the first control after removal of the catheter tube. According to (Bruschini et al., 2011), IU in
Benign Prostatic Hyperplasia (BPH) surgery is rare, but $30-40 \%$ of clients experience early IU.

Clients who experience urinary incontinence will reduce social interactions, physical activity, and are associated with poor health, emotional and psychological well-being and sexual intercourse disorders which have an impact on their quality of life (Dumoulin et al., 2015). Research conducted found that of the 30 elderly who experienced urinary incontinence 28 elderly or $93.3 \%$ experienced poor quality of life(Rani et al., 2020).

Early incontinence can occur in up to $30-40 \%$ of clients. IU after BPH surgery requires careful management and evaluation. Early incontinence usually occurs which can be due to irritating symptoms such as healing of the fossa or instability of the bladder muscles due to prolonged BPH (Zuhirman et al., 2017). The bladder will not fill and contract when the catheter is inserted, therefore, the bladder will eventually lose its tone (atony). The detrusor 
muscle may not be able to contract and the client cannot eliminate the urine if this happens and the catheter is removed. As the client recovers and the drainage tube is removed, the client shows frequent urination due to the inability to achieve bladder control quickly and

a burning sensation after the catheter is removed (Hinkle \& Cheever, 2018). From the initial survey conducted at the Urology Department of Muhammadiyah Hospital, from 10 clients who were control, there were 3 clients who experienced urinary incontinence, but data

on the decline in quality of life were not documented. In other studies, it is stated that $\mathrm{BPH}$ occurs mainly at the age of over 40 years

The treatment plan depends on the cause, severity of the obstruction, and the client's condition (Hinkle \& Cheever, 2018). Contemporary data suggest that $10 \%$ of clients require surgery (Bruschini et al., 2011). According to (Zuhirman et al., 2017), TURP is still the gold standard for managing benign $\mathrm{BPH}$ by reducing the complication rate. TURP is the standard surgical treatment for BPH clients. TURP is the treatment of choice for the prostate, but has a significant postoperative morbidity rate. TURP can lead to complications such as postoperative bleeding, urethral stricture, urinary incontinence, retrograde ejaculation, and TURP syndrome (Janice \& Kerry, 2018; Zuhirman et al., 2017).

TURP is the most common procedure and can be done through an endoscope. Surgical and optical instruments are inserted directly through the urethra into the prostate, which can then be viewed directly. The gland is removed in small incisions with an electric cutting loop. This procedure does not require incisions, and is used for glands of various sizes and is ideal for clients who have small glands and who are considered to have a bad surgical risk (Hinkle \& Cheever, 2018).

This approach shortens the day of stay, however, strictures often arise and re-treatment may be required (Hinkle \& Cheever, 2018). According to (Zuhirman et al., 2017), the stricture rate varies from $2.2 \%$ to $9.8 \%$. Stricture is a condition in which the urethra is narrowed due to a scar on the wall of the urethra so that it blocks the flow of urine which can increase pressure on the bladder and increase the activity of the detrusor muscle to push urine out. As a result, the client's inability to control urination (BAK) and the desire for $B A K$ is more frequent and sudden.

According to (Bruschini et al., 2011) the causes of IU post TURP are highly multifactorial, including urinary sphincter insufficiency (USI) or bladder dysfunction (BD) which is defined as decreased development or detrusor overactivity (DO). USI occurs as a result of injury to the sphincter mechanism and incontinence is usually associated with bladder dysfunctions (BD), which includes detrusor overactivity (DO). In addition, DO is associated with increased bladder muscle pressure with urine storage which can result in IU.

Continuous urinary incontinence with the impact it brings causes the quality of life and self-esteem of post-TURP clients to decrease. Conditions of quality of life and low self-esteem cause anxiety about life and can eventually lead to depression. Handling inkontinentia urine depends on the causes (Hinkle \& Cheever, 2018). Successful management depends on the type of IU and the contributing factors. IU can be temporary or reversible, after the underlying cause has been resolved, the client's urination pattern will return to normal, so it is necessary to evaluate the nursing and/or medical treatment (Hinkle \& Cheever, 2018).

Hospital standards for treating urinary incontinence are pharmacological therapy and intermittent insertion of catheter tubes. The drugs given are a class of urinary tract spasmolytic drugs that are not free from side effects. The intermittent catheter is inserted for 2 weeks with a success rate of $80 \%$, but $20 \%$ of clients still experience recurrence within 2 days after removal of the catheter tube (preliminary study at Muhammadiyah Hospital Lamongan). Catheter placement has a side effect of swelling of the urethra and can lead to urinary tract infections and sepsis (Perry et al., 2014).

\section{MATERIALS AND METHODS}

This study used a true experimental design with a pre-post test control group design. The population in this study posted TURP clients who control at the Poli Urology Muhammadiyah Hospital Lamongan, recorded as many as 162 people. Samples were clients post TURP in Poli Urology Hospital Muhammadiyah Lamongan that meet the criteria of inclusion as follows: Klien post-TURP 1 week after discharge streamng catheter (3 weeks post-TURP), klien understand instructions either orally or in writing characterized by the client is able to explain the researcher's question again, the client is cooperative, the client has a legitimate, the age is less than 65 years The exclusion criteria: client cognitively impaired. Samples were involved in the research have amounted to 32 people, case: 16 people and control 16 votes, with the technique of sampling used by systematic random sampling (Dahlan, 2011)

The independent variable in this study is the Kegel exercise. The dependent variable in this study is quality of life. Instruments of 
research that used the intervention of this research is SAP, guidebooks Kegel exercise, Kegel exercise workout schedule cards, and the observation sheet activities. While the tools used to measure the dependent variable of the study consist of WHOQOL-BREF, which is a short version of WHOQOL 100. WHOQOLBREF consists of 26 items, (Refitlianti \& Isfandiari, 2017; Vahedi, 2010)

Location and Time of Research This research was conducted at the Urology Poly at the Muhammadiyah Hospital in Lamongan, from February to June 2018. Descriptive data analysis is presented to explain the characteristics of respondents including age, education, occupation, and whether or not they have had operations displayed in the form of distribution values and test frequency. independent t-test to compare differences in the data pre in the control and treatment groups and post in the treatment group and control, as well as the use of multivariate analysis MANOVA with the level of significance 0,05 (Nursalam, 2016)

\section{RESULT}

In this chapter, data regarding the results of research is presented through data collection obtained on March 13 - June 1, 2018, at the Urology Poly at Muhammadiyah Lamongan Hospital with 32 respondents. The presentation of the results of this study includes an overview of the research location, general data about the characteristics of the respondents, and specific data about urinary incontinence, and quality of life for post TURP clients.

\section{Characteristics of Respondents}

Demographic characteristics data of respondents describe the characteristics of respondents including age, education, occupation, and history of operations.

Table 1 Distribution of Respondents Based on Characteristics in the Treatment Group and Control Group at Urology Poly, RSM Lamongan 2018

\begin{tabular}{llllll}
\hline $\begin{array}{l}\text { Characteristics } \\
\text { Respondents }\end{array}$ & \multicolumn{2}{l}{ Treatment $(\mathbf{n}=\mathbf{1 6})$} & Control $(\mathbf{n}=\mathbf{1 6})$ & Homogeneity \\
\hline Age & & & & \\
\hline Mean \pm SD & 60.25 & 4,740 & 60.44 & $\begin{array}{l}3,864 \\
65\end{array}$ & $\mathrm{p}=0.903$ \\
Min-Max & 50 & 65 & 54 & & \\
\hline Education & & & & & \\
\hline Basic education & 11 & $68.75 \%$ & 12 & $75 \%$ & $\mathrm{p}=0.780$ \\
Middle education & 5 & $31.25 \%$ & 4 & $25 \%$ & \\
\hline Profession & & & & & \\
\hline Work & 11 & $68.75 \%$ & 10 & $62.50 \%$ & $\mathrm{p}=0.889$ \\
Does not work & 5 & $31.25 \%$ & 6 & $37.50 \%$ & \\
\hline Operation history & & & & & \\
\hline Never & 13 & $81.25 \%$ & 14 & $87.50 \%$ & $\mathrm{p}=0.468$ \\
Ever & 3 & $18.75 \%$ & 2 & $12.50 \%$ & \\
\hline
\end{tabular}

Table 1 shows that the characteristics of the respondents have a mean age of 60.25 years (SD $=4.740$ years $)$ for the treatment group and 60.44 years $(S D=3.864$ years $)$ for the control group with the same maximum age of 65 years. The results of statistical tests using A NOVA showed no difference in the age characteristics of the respondents of the two groups with $p=0.903$. Characteristics of respondents based on education are more than some with basic education in the treatment group $(68.75 \%)$ and control (75\%). The results of statistical tests using Mann Whitney showed that there was no difference in educational characteristics among respondents in the two groups with $p=0.780$, the characteristics of respondents based on occupation in the treatment group who worked as many as 11 people or $68.75 \%$ and in the control group respondents who worked as many as 10 people or $62.50 \%$. The results of statistical tests using the Chi-Square Test showed that there was no difference in job characteristics in the two groups with $p=0.889$, and the characteristics of respondents based on a history of surgery were found to have never had surgery, namely $81.25 \%$ in the treatment group and $87.50 \%$ in the control group. The results of statistical tests using the Chi-Square Test showed no difference in the characteristics of the history of surgery in the two groups with $p=0.468$. 
Table 2 Normality Test of Quality of Life for Post TURP Clients at Urology Poly, RSM Lamongan, period 13 March - 1 June 2018

\begin{tabular}{llllllll}
\hline Variable & Group & $\mathbf{n}$ & $\begin{array}{c}\text { Normality } \\
(\mathrm{p} \text { value })\end{array}$ & Group & $\mathbf{n}$ & $\begin{array}{c}\text { Normality } \\
(\mathrm{p} \text { value })\end{array}$ & $\begin{array}{c}\text { Paired } \\
\text { t-test }\end{array}$ \\
\cline { 2 - 8 } & \multicolumn{7}{c}{ Pre test } \\
\hline \multirow{2}{*}{$\begin{array}{l}\text { Quality of } \\
\text { Life }\end{array}$} & Treatment & 16 & 0.890 & Treatment & 16 & 0.636 & $\mathrm{p}=0.000$ \\
\cline { 2 - 8 } & Control & 16 & 0.350 & Control & 16 & 0.571 & $\mathrm{p}=0.422$ \\
\cline { 2 - 8 } & Total & $\mathbf{3 2}$ & & Total & $\mathbf{3 2}$ & & \\
\hline
\end{tabular}

Table 2 shows that the Shapiro-Wilk normality test on the quality of life data of the treatment group obtained a pre-test significance value of 0.890 and a post-test of 0.636 . While the data in the control group, the pre-test significance value was 0.350 and the post-test was 0.571 , thus it can be concluded that the quality of life score data for the treatment and control groups were normally distributed. The result from statistical test paired t-test on group treatment $p=0.000$ which means that there are differences in the quality of life significantly on the client post TURP. Whereas in the control group the results of the Paired t-Test test were $p=0.422(p>0,05)$ which means that there is no significant difference in the quality of life of post TURP clients.

Table 3 Manova Test Effect of Kegel Exercise on Quality of Life of Post TURP Clients at Urology Poly, Muhammadiyah Hospital Lamongan, period 13 March - 1 June 2018

\begin{tabular}{lccccc} 
Group & N & Pre & Post & Std. Deviation & P \\
\hline Treatment & 16 & 52.84 & 60.42 & 4,740 & \multirow{2}{*}{0.045} \\
\hline Control & 16 & 48.56 & 50.46 & 3,864 & \\
\hline
\end{tabular}

Table 3 shows that the mean (pre) quality of life in the treatment group was 48.560 (SD $=$ $9.421)$ and the control group was $50.470(S D=8.112)$. The results of the Manova statistical test using the Wilks Lambda method in the control and treatment groups showed a value of $p=0.045(p<0.05)$, which means that there was a difference in the quality of life scores between the treatment and control groups before the $\mathrm{M} \mathrm{Kegel} \mathrm{exercise} \mathrm{intervention.}$

\section{DISCUSSION \\ Effect of Kegel exercise on the quality of life of post-op TURP patients}

The quality of life scores in the treatment group after being given the Kegel exercise intervention showed a significant increase compared to the control group. Improved quality of life on the WHOQOL-BREF questionnaire, there was a change in decreasing urinary incontinence which could improve sleep quality, improve social relationships and the ability to perform daily activities that can increase self-confidence. This is probably due to the decrease in urinary incontinence, the client is more comfortable and confident in his ability to hold urine so that he can socialize or socialize without worrying about urine leakage (Sandhu, 2010; Sulistyaningsih, 2015). It is contrary to the back with findings that impact on the quality of life seem less clear, although the trend is the quality of life that is better observed in the intervention group (Tienforti et al., 2012).

In a study entitled Preoperative Pelvic Floor Muscle Exercise for Early Continence After Radical Prostatectomy with a mechanism of thirty days before surgery, respondents were given PMFT training guided by a therapist twice a week for 30 minutes (and for 30 minutes every day at home). Then 48 hours after the removal of the exercise catheter was carried out twice per week for one month, it was found that the pelvic floor muscle exercises performed before and continued after prostate surgery had significant results that could reduce incontinence and improve quality of life (Centemero et al., 2010; Overgård et al., 2008) - In patients with stricture of the urethra posterior or contracture of neck of bladder urine were associated with incontinence of urine that is severe, the implantation of the sphincter urinary artificial as a step both allow verification of the results urethroplasty end-to-end before or anastomosis and uses field operations specifically for clicking reduce risk. implant prosthesis (Nicholson et al., 2017).

There was no difference in the quality of life score of post- TURP clients before the Kegel exercise intervention. The mean scores of the two groups showed almost the same scores, namely 50.47 (control group) and 48.56 (treatment group). Both groups had low quality of life scores in the domains of physical condition and social relationships. There is evidence for a widespread recommendation that pelvic floor muscle $k$ helps all types of urinary incontinence, and it is necessary to follow in a pelvic floor muscle training program for at least three months (Pratiwi et al., 2020; 
Price et al., 2010)The results of the research of other states that old decreased complaint dribbling on respondents who dutifully perform Kegel's exercise stops, starting on day 13, was on the respondent disobedient do Kegels exercise stops, starting on day $20(p=0.004 ; \alpha$ $=0.05)$. Results of the analysis is further explained there is a difference that is meaningful to the average long time complaint dribbling respondents between the level of compliance do Kegel's exercise in group intervention and control group $(p=0,0005 ; \alpha$ $=0.05$ ) (Madjid et al., 2011).

The mean age of the respondents in both groups was in their 60s. This age is in middle age which has the development of having let go of children, living together with a partner. A man has begun thinking about creating a

harmonious relationship with his wife had diminished as a work of his young age. But with this situation, the client feels inferior. They want to get well soon and be able to return to their activities without any disturbance. If this situation is left unchecked, the client will likely experience depression and their quality of life will get worse. One of which affect the quality of life are the things in life, it is associated with the task of development and the stress caused by the task (Alcaraz et al., 2016). The events in life are closely related to the developmental tasks

that must be undertaken, and sometimes a person's ability to carry out these tasks creates certain stress. This is in accordance with the theory which states that one of the strongest causes of depression is stress and the age above 40 to 60 years is a period of special vulnerability to experience anxiety and depression due to stress or difficulties in social functioning, work, and daily life (Nilasari, 2013).

The results of the analysis of

respondents based on a history of surgery

show that most respondents have never experienced surgery so that their quality of life is in a low category. At the time of collecting the initial data, most of the respondents complained that they felt they could not enjoy life freely, had limited activities and social interactions, and did not have the opportunity to have fun or recreation due to the inability to hold urine. The client also said that he felt uncomfortable in his relationship with his wife. This emotional response causes their quality of life to decline. Emotions respond of clients to social activities, emotional, work and family relationships, a sense of fun or happiness, compatibility between expectation and reality that is, their ability to make socialization with other people is an indicator of the quality of their lives (Cella et al., 2011).

More than some clients work, work is the result of client interactions with other people. IU has been found to reduce social interactions, physical activity, and is associated with poor health, emotional and psychological well-being and impaired sexual relations which have an impact on their quality of life (Dumoulin et al., 2015). Kegel exercises are exercises that do not require extra energy, can be done anywhere while relaxing, while listening to music or watching television, can also be done after finishing the workshop. Such situations can cause feelings of pleasure, happiness and relaxation so as to increase passion for life and reduce feelings of inferiority. Researchers from the University of Vermont found that just 20 minutes of exercise can lead to a better mood for 12 hours. Exercising can affect a person's mental condition when in a bad mood (Maharani, 2014).

\section{CONCLUSION}

Kegel exercise has been proven to improve the quality of life for post TURP clients at the Urology Poly at Muhammadiyah Hospital in Lamongan. Hospital nurses are expected to be able to use the Kegel exercise intervention as first-line therapy in overcoming urinal incontinence and to improve the quality of life and utilize the Kegel exercise manual used in this study. For the next researchers, it is hoped that they can conduct research again using Kegel exercise interventions as a solution to reduce urinary incontinence and quality of life for post-TURP clients in a wider population by increasing the reach of the research population and controlling the evaluation of the process. For the hospital, it is hoped that it can be used as a reference in the preparation of SOPs on Kegel exercises by the nursing committee.

\section{REFERENCES}

Alcaraz, A., Carballido-Rodríguez, J., UndaUrzaiz, M., Medina-López, R., RuizCerdá, J. L., Rodríguez-Rubio, F., GarcíaRojo, D., Brenes-Bermúdez, F. J., CózarOlmo, J. M., Baena-González, V., \& Manasanch, J. (2016). Quality of life in patients with lower urinary tract symptoms associated with $\mathrm{BPH}$ : change over time in real-life practice according to treatmentthe QUALIPROST study. International Urology and Nephrology, 48(5), 645-656. https://doi.org/10.1007/s11255-0151206-7

Bruschini, H., Simonetti, R., Antunes, A. A., \& Srougi, M. (2011). Urinary incontinence following surgery for BPH: the role of aging on the incidence of bladder dysfunction. International Braz j Urol, 
37(3), 380-387.

Cella, D., Nowinski, C., Peterman, A., Victorson, D., Miller, D., Lai, J.-S., \& Claudia Moy. (2011). The Neurology Quality of Life Measurement Initiative. NIH Public Access, 23(1), 1-7. https://doi.org/10.1016/j.apmr.2011.01.02 5.The

Centemero, A., Rigatti, L., Giraudo, D., Lazzeri, M., Lughezzani, G., Zugna, D., Montorsi, F., Rigatti, P., \& Guazzoni, G. (2010). Preoperative pelvic floor muscle exercise for early continence after radical prostatectomy: a randomised controlled study. European Urology, 57(6), 10391044.

Dahlan, M. S. (2011). Statistik untuk kedokteran dan kesehatan. Penerbit Salemba.

Dumoulin, C., Hay-Smith, J., Habée-Séguin, G. Mac, \& Mercier, J. (2015). Pelvic floor muscle training versus no treatment, or inactive control treatments, for urinary incontinence in women: a short version Cochrane systematic review with metaanalysis. Neurourology and Urodynamics, 34(4), 300-308.

Hinkle, J. L., \& Cheever, K. H. (2018). Brunner and Suddarth's textbook of medicalsurgical nursing. Wolters kluwer india Pvt Ltd.

Janice, L. H., \& Kerry, H. C. (2018). Brunner \& Suddarth: Vol. (14).

Madjid, A., Irawaty, D., \& Nuraini, T. (2011). Penurunan Keluhan Dribbling Pasien Pasca Transurethral Resection Of The Prostate Melalui Kegel's Excercise. Jurnal Keperawatan Indonesia, 14(2), 121-126.

Maharani, D. (2014). Olahraga Punya Efek Bikin Bahagia. Kompas. https://lifestyle.kompas.com/read/2014/0 9/21/113147923/Olahraga.Punya.Efek.Bi kin.Bahagia.

Nicholson, H. L., Al-Hakeem, Y., Maldonado, J. J., \& Tse, V. (2017). Management of bladder neck stenosis and urethral stricture and stenosis following treatment for prostate cancer. Translational Andrology and Urology, 6(Suppl 2), S92S102.

https://doi.org/10.21037/tau.2017.04.33

Nilasari, S. (2013). Positive psychotherapy untuk menurunkan tingkat depresi. University of Muhammadiyah Malang.

Nursalam, N. (2016). Metodologi Penelitian IImu Keperawatan. Salimba Medika.

Overgård, M., Angelsen, A., Lydersen, S., \& Mørkved, S. (2008). Does physiotherapist-guided pelvic floor muscle training reduce urinary incontinence after radical prostatectomy?: A randomised controlled trial. European Urology, 54(2), 438-448.

Perry, A. G., Potter, P. A., Stockert, P. A., \& Hall, A. (2014). Fundamental of Nursing,. St Louis. Elsevier Mosby.

Pratiwi, D. R., Yusniar, F., Susanti, I. A., \& Sukartini, T. (2020). Pelvic Floor Muscle Training (PFMT) to Reduce Urinary Incontinence Post Radical Prostatectomy in Patients with Prostate Cancer: A Systematic Review. Jurnal Ners, 15(2), 164-172. https://doaj.org

Price, N., Dawood, R., \& Jackson, S. R. (2010). Pelvic floor exercise for urinary incontinence: a systematic literature review. Maturitas, 67(4), 309-315.

Rani, M., Cadiz, M., S, J. K., Amin-ong, A. J., \& Lisa, T. (2020). Urogynecology. Journal of Obstetrics and Gynaecology Research, 46(S1), https://doi.org/10.1111/jog.14464

Refitlianti, A., \& Isfandiari, M. A. (2017). Hubungan Dukungan keluarga Terhadap Kualitas Hidup Penderita Kusta Kecacatan Tingkat 2. Jurnal IImiah Kesehatan Media Husada, 6(2), 159-174.

Sandhu, J. S. (2010). Treatment options for male stress urinary incontinence. Nature Reviews Urology, 7(4), 222.

Sulistyaningsih, D. R. (2015). Latihan Otot Dasar Panggul Efektif Untuk Mengatasi Inkontinensia Urin Pada Klien Post Operasi Prostatectomy. NURSCOPE: Jurnal Penelitian Dan Pemikiran IImiah Keperawatan, 1(2), 1-8.

Tienforti, D., Sacco, E., Marangi, F., D’Addessi, A., Racioppi, M., Gulino, G., Pinto, F., Totaro, A., D’Agostino, D., \& Bassi, P. (2012). Efficacy of an assisted lowintensity programme of perioperative pelvic floor muscle training in improving the recovery of continence after radical prostatectomy: a randomized controlled trial. BJU International, 110(7), 10041010.

Vahedi, S. (2010). World Health Organization Quality-of-Life Scale (WHOQOL-BREF): Analyses of Their Item Response Theory Properties Based on the Graded Responses Model. Iranian Journal of Psychiatry, 5(4), 140-153. http://www.ncbi.nlm.nih.gov/pubmed/229 52508\%0Ahttp://www.pubmedcentral.nih. gov/articlerender.fcgi?artid=PMC339592 3 
Zuhirman, Z., Juananda, D., \& Lestari, P.

(2017). Gambaran Komplikasi

Transurethral Resection of the Prostate

pada Pasien Benign Prostatic

Hyperplasia. Jurnal IImu Kedokteran,

10(1), 44.

https://doi.org/10.26891/jik.v10i1.2016.44

$-53$ 